\title{
Species-environment relationships of fish and map-based variables in small boreal streams: Linkages with climate change and bioassessment
}

\section{Tapio Sutela $^{1}$ (D) | Teppo Vehanen ${ }^{2}$ (D) | Pekka Jounela ${ }^{3}$ | Jukka Aroviita}

\author{
${ }^{1}$ Natural Resources Institute Finland (Luke), \\ Oulu, Finland \\ ${ }^{2}$ Natural Resources Institute Finland, \\ Helsinki, Finland \\ ${ }^{3}$ Natural Resources Institute Finland, Turku, \\ Finland \\ ${ }^{4}$ Finnish Environment Institute, Freshwater \\ Centre, Oulu, Finland \\ Correspondence \\ Tapio Sutela, Natural Resources Institute \\ Finland, Oulu, Finland. \\ Email: tapio.sutela@luke.fi
}

\begin{abstract}
Species-environment relationships were studied between the occurrence of 13 fish and lamprey species and 9 mainly map-based environmental variables of Finnish boreal small streams. A self-organizing map (SOM) analysis showed strong relationships between the fish species and environmental variables in a single model (explained variance $55.9 \%$ ). Besides basic environmental variables such as altitude, catchment size, and mean temperature, land cover variables were also explored. A logistic regression analysis indicated that the occurrence probability of brown trout, Salmo trutta L., decreased with an increasing percentage of peatland ditch drainage in the upper catchment. Ninespine stickleback, Pungitius pungitius (L.), and three-spined stickleback, Gasterosteus aculeatus L., seemed to benefit from urban areas in the upper catchment. Discovered relationships between fish species occurrence and land-use attributes are encouraging for the development of fish-based bioassessment for small streams. The presented ordination of the fish species in the mean temperature gradient will help in predicting fish community responses to climate change.
\end{abstract}

\section{KEYWORDS}

boreal, climate change, land use, logistic regression, self-organizing map, small stream

\section{1 | INTRODUCTION}

Studying the relationship between species and their environment is at the core of ecology. Modeling this relationship has long been performed, using a wide array of methods (Domisch et al., 2015; Franklin, 1995; Guisan \& Zimmermann, 2000). The focus in developing these models may be to study species-environment relationships or to predict the occurrence of the studied species. In fisheries research, the identification of the environmental variables that characterize fish distributions has been one of the main objectives (Nelson et al., 1992; Rieman \& Mclntyre, 1995). Predictive models may help in fish-based bioassessment (Brosse et al., 2001; Oberdorff et al., 2001, 2002) and in focusing inventory and management activities on areas where species are considered likely to occur (Porter et al., 2000).

Several studies have indicated that field-measured site-scale (local) variables such as stream width, water depth, water chemistry, riverbed substrate, flowrate, undercut banks, canopy cover, riparian vegetation, and the slope at the sampling site can predict the occurrence of fish species (Gorman \& Karr, 1978; Terra et al., 2016; Watson \& Hillman, 1997). However, these field measurements are laborious and thus demanding for adoption as predictors of species 
occurrence in fisheries management, for example. An easier way to predict species occurrence would be to use large-scale map-based (regional) variables such as the size of the upper catchment, the elevation, and land use in the upper catchment (Porter et al., 2000). Indeed, catchment-scale variables can have a greater impact than site-scale variables on stream fish assemblages (DeRolph et al., 2015; Mitsuo, 2017).

The process of taking natural landscapes for human use can cause detrimental effects on terrestrial and aquatic ecosystems (Huston, 2005; Pugh et al., 2020). For example, increased land use for agriculture, urban areas, and forestry can impact fish populations through alterations in stream hydrology, geomorphology, water quality, sedimentation, riparian vegetation, and habitat heterogeneity, eventually leading to species loss or replacement (Allan et al., 1997; Lange et al., 2014; Pugh et al., 2020). Recent developments in geographical information systems (GIS) technology (Lü et al., 2019) have facilitated easy access to a wide range of catchment characteristics above any site of a stream network. These catchment characteristics, typically expressed as the percentage coverage of the upper catchment, are extensively used in studying the effects of land use on stream biota.

About $80 \%$ of the millions of kilometers of European river networks consist of small streams, commonly known as brooks, creeks, or headwaters (Kristensen \& Globevnik, 2014). Small headwater streams are important contributors to aquatic biodiversity and may suppress the negative impacts of anthropogenic stress on downstream reaches (Baattrup-Pedersen et al., 2018; Burdon et al., 2016). However, in the European Water Framework Directive (WFD; European Commission, 2000), small streams with a catchment size of $<10 \mathrm{~km}^{2}$ are mostly omitted from river basin management plans or merged into larger water bodies (Baattrup-Pedersen et al., 2018; Kristensen \& Globevnik, 2014).

In this study, we chose to examine fish in small streams for some specific reasons. We inferred that in small streams/catchments, a single land-use attribute such as an urban area can easily reach high coverage, and therefore, the effect of land use on fish species occurrence should be relatively easy to trace. In small streams, the upstream catchment area is always located relatively near the sampling site, and the impact of land use should therefore be more direct. Indeed, proximity to the stream has appeared an important factor in estimating the impact of land use on stream biota (Wang et al., 2001). Small streams with a small volume of water also have only a limited ability to dilute pollutants such as nutrients from agriculture (Kristensen \& Globevnik, 2014). Small tributary streams have appeared to be particularly sensitive to nutrient enrichment (Bussi et al., 2018). The impact of human activities is therefore potentially greater on small water bodies than on larger ones (Kristensen \& Globevnik, 2014).

Our main aims in this study were (1) to explore the relationship of map-based environmental variables and the occurrence of fish species in small boreal streams; (2) extract fish species clusters and evaluate their ecological relevance; (3) study species occurrence in relation to annual mean temperature from the perspective of the climate change in this region; and (4) identify species-specific responses to man-induced pressures for the future development of diagnostic indices in bioassessment of small boreal streams.

\section{2 | MATERIAL AND METHODS}

Altogether, 11 environmental variables were measured (Table 1). The studied area covered Southern and Central Finland in the boreal region from about $60^{\circ}$ to $67^{\circ}$, which are mostly covered with coniferous forest. The highest altitude among sampling sites was about $300 \mathrm{~m}$ in the studied territory characterized by lowlands (Table 1). The variables were map-based, with the exception of one fieldcollected variable, water temperature at sampling (electrofishing). Upstream catchment boundaries were delineated for each site with Geographical Information System, using the Digital Elevation Model (DEM) raster database from National Land Survey of Finland (NLS) and vector data of Drainage Basins in Finland (Finnish Environment Institute, SYKE). Only sites with a catchment area $<100 \mathrm{~km}^{2}$ were

TAB LE 1 Basic statistics of the environmental variables studied

\begin{tabular}{|c|c|c|c|c|}
\hline & Mean & Median & Min. & Max. \\
\hline Latitude ( ${ }^{\circ}$, WGS84) & 62.568 & 62.120 & 60.103 & 66.989 \\
\hline Altitude (m) & 98.0 & 84.9 & 1.9 & 305.8 \\
\hline Catchment area $\left(\mathrm{km}^{2}\right)$ & 16.2 & 9.6 & 0.2 & 98.9 \\
\hline Water temperature at sampling $\left({ }^{\circ} \mathrm{C}\right)$ & 11.0 & 11.0 & 1.3 & 21.7 \\
\hline Annual mean air temperature $\left({ }^{\circ} \mathrm{C}\right)$ & 2.8 & 3.2 & -0.8 & 5.2 \\
\hline Annual precipitation (mm) & 599 & 608 & 471 & 674 \\
\hline Urban areas (\%) & 11.0 & 1.7 & 0 & 78.7 \\
\hline Fields (\%) & 6.4 & 1.5 & 0 & 53.3 \\
\hline Open mires (\%) & 4.1 & 0.7 & 0 & 45.2 \\
\hline Lakes (\%) & 2.1 & 0.4 & 0 & 25.6 \\
\hline Ditched peatland (\%) & 9.3 & 7.2 & 0 & 49.0 \\
\hline
\end{tabular}

Note: The last five variables refer to the percentages of the catchment area above the electrofishing site. 
included in the study. The proportions of different land covers in the catchment areas were extracted from the CORINE Land Cover 2012 data. The quantity of forest drainage by ditching was estimated as a percentage of ditched peatlands from the drainage data of the Finnish Environment Institute. Annual air temperature and precipitation data were derived from the WorldClim database (Hijmans et al., 2005).

Electrofishing data from small Finnish streams were gathered mainly from a national database (Hertta/Koekalastusrekisteri) managed by the Natural Resources Institute Finland (Luke) and hosted by the SYKE. Additional data were acquired from Metsähallitus (a state-owned enterprise responsible for the management of stateowned land and water areas). The total number of single-run electrofishing samples was 776 , conducted at 487 sites, indicating that some of the sites were sampled more than once. As a rule, repeated sampling at the same site was performed at different years. Most of the sampling had been performed at the period 2000-2020. The electrofishing sites usually represented wadable riffles with stony bottoms. Escape nets were not used at any of the sampling sites, which typically covered $50-150 \mathrm{~m}^{2}$. As the electrofishing sampling had been performed in July-October, natural seasonal decline in stream water temperatures was reflected in the measured temperatures. European standard EN 14011:2003 (Water quality-sampling of fish with electricity) was followed in sampling. Fish data were converted to species presence/absence for all analyses in this study.

\section{1 | Statistical methods}

The occurrence of the fish and lamprey species in relation to the environmental variables was modeled using binary logistic regression (BLR) analysis. In the preprocessing phase, highly (>0.7) multicollinear predictors (latitude and precipitation) were removed from the BLR analysis. The final number of environmental variables (predictors) accepted for BLR analyses was therefore nine (Table 1). To avoid pseudoreplication, only one randomly selected electrofishing sample per site was included $(N=487)$. Rare species, present in less than $3 \%$ of the sites, were excluded from the analysis, resulting in 13 species for the modeling (Table 2). The statistical significance of each predictor was assessed by a chi-square test, with $p$-value $<0.05$ indicating a significant impact. To assess the fit of the models to our data, Nagelkerke (pseudo) $R^{2}$ was calculated for each model. Also Hosmer-Lemeshow goodness-of-fit test (Hosmer $\&$ Lemeshow, 1989) was used with $p$-value $>0.05$ indicating an acceptable model fit. Accuracy of the BLR model was calculated as the percentage (\%) of the studied sites where the presence or absence of a fish species was predicted correctly. BLR analyses were conducted by IBM SPSS Statistics 26 .

The interactions between 13 species occurrences and 9 environmental variables were further studied using a self-organizing map (SOM, Kohonen, 1982, 2001). In contrast to BLR, all species were processed in a single model. In general, SOM is an unsupervised dimensionality reduction method that visualizes high-dimensional data in a low-dimensional map. In ecology, SOM has been extensively implemented for information extraction, visualization, and clustering of community data (Chon, 2011). Compared to some conventional statistical methods (e.g., PCA, NMDS) used for community ordination, SOM has performed well, for example, by allowing the visualization of interspecific association even if it differs in different parts of the data space (Giraudel \& Lek, 2001). In addition, the network tolerates noise (Vesanto et al., 1998) by allowing outlying samples to affect only one map unit and its neighborhood. The other areas of the map are not affected by these data (Kaski, 1997). In this study, unsupervised SOM was used to patternize 22 predictors (13 species +9 environmental variables) and 487 samples with a twodimensional map which were then grouped, that is, clustered. This

TAB LE 2 Goodness-of-fit statistics for the BLR models by fish species, predicting the probability of fish species presence $(N=487)$

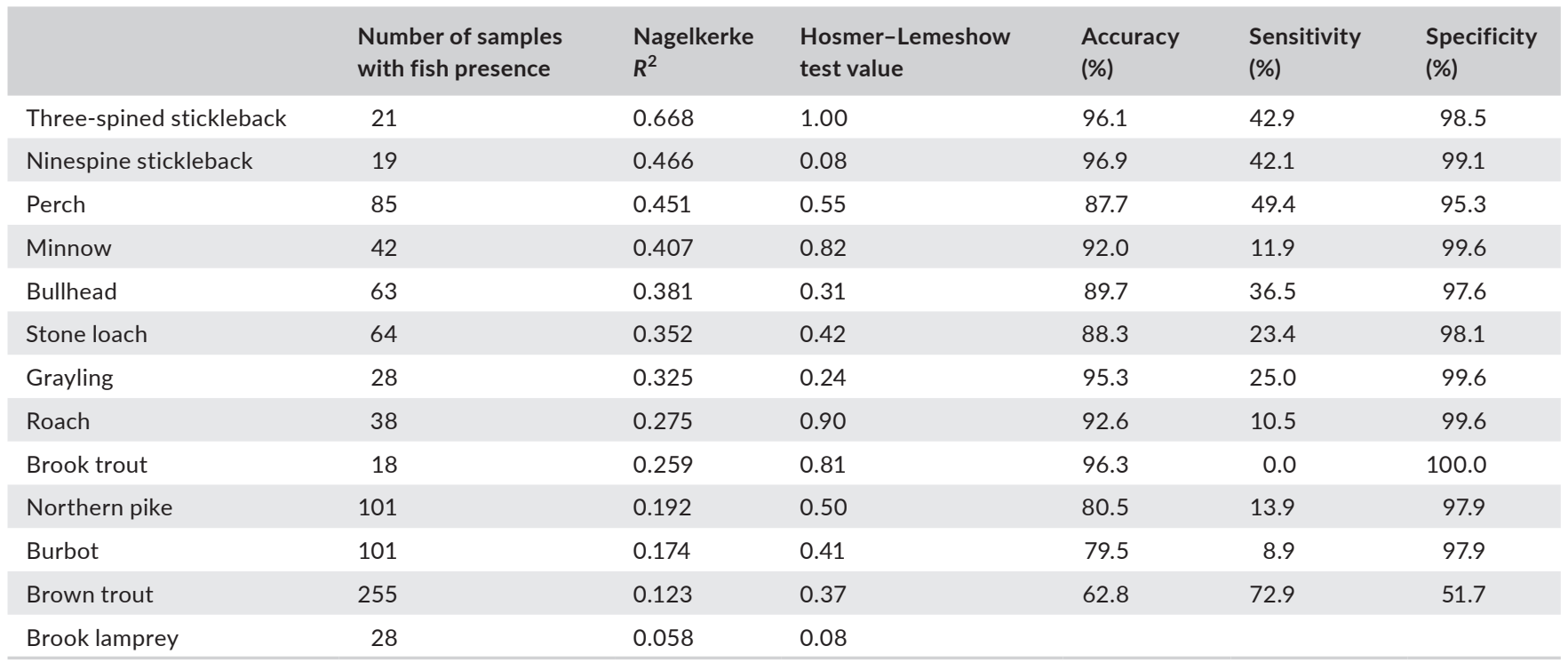

Note: BLR model was not statistically significant for brook lamprey. 
two-stage procedure, first using SOM to produce the prototypes that are then clustered in the second stage, has been found to perform well compared with direct clustering of the data (Vesanto \& Alhoniemi, 2000). The two dimensions of SOM were clustered using the k-means algorithm (Kohonen, 2014). The Davies Bouldin validity index (Davies \& Bouldin, 1979), which measures between- and intra-cluster distances, was used as a performance criterion. In the parameter optimization, SOM net sizes (number of nodes in $\mathrm{x}$ and $y$ dimensions) and the number of clusters in parameter $\mathrm{k}$ were altered, using a grid search until the minimum of the Davies Bouldin index was found, using the elbow criterion. In parameter optimization, the SOM net size roughly followed the map size rule (of thumb) of Vesanto and Alhoniemi (2000; $N$ (nodes) $=5 \times \operatorname{sqrt}\left(\mathrm{N}_{\text {rows }}\right)$ ). Each trial SOM consisted of 10,000 training rounds. In the preprocessing phase, the occurrence of each fish species was dummy (zero or one, absence or presence) coded. All predictors were then normalized with a zeroed mean and variance of one. The learning rate function was inverse of time, which ensures that all samples have an approximately equal influence on the results. The statistical analyses were performed using RapidMiner software (version Studio Large 9.7.000., https://rapidminer.com /, Mierswa et al., 2006).

\section{3 | RESULTS}

As anticipated for the small catchment areas of this study, there was high variation among sites in the catchment land cover variables (Table 1). The average catchment size and altitude at the sites oc cupied by each of the fish species varied considerably. To illustrate this, the positioning of three species in the catchment size-altitude space suggests that three-spined stickleback occupied small lowaltitude brooks, whereas brook trout, Salvelinus fontinalis (Mitchill 1814), dwelled in tributaries, and grayling, Thymallus thymallus L., in larger streams (Figure 1).

The BLR models were statistically significant $\left(\chi^{2(9)}=35.4-154.7\right.$, $p<0.005)$ for all fish species, with the exception of brook lamprey, Lampetra planeri (Bloch), $\left(\chi^{2(9)}=10.1, p=0.340\right)$. The highest Nagelkerke $R^{2}$ values were recorded for the two stickleback species (Table 2). In Hosmer-Lemeshow goodness-of-fit tests, the $p$-values were $>0.08$ for all the models, indicating an acceptable model fit for the data. The accuracy of the models was usually high, ranging from $96.9 \%$ with ninespine stickleback to $62.8 \%$ with brown trout. The absence of fish species was predicted by the models much more correctly than presence, as indicated by specificity (average $94.6 \%$, SD 13.6\%) versus sensitivity (average 28.1\%, SD 21.1\%) (Table 2).

The statistical performance of the best SOM model including all species was good (explained variance $55.94 \%$, Davies Bouldin index $0.71)$. The net size $(11 \times 11=121$ nodes $)$ of the best-performing SOM model roughly followed the map size rule of thumb (110 nodes). The smallest Davies Bouldin index was attained with 4 clusters (Figure 2). Cluster 2 at the top right of the SOM was occupied by bullhead, burbot, Lota lota (L.), grayling, and minnow, Phoxinus phoxinus (L.), and characterized by a large catchment area, high altitude, and low mean temperature (Figure 2, Table 3). Cluster 1 at the top left of the SOM was occupied by perch, Perca fluviatilis L., roach, Rutilus rutilus (L.), and northern pike, Esox Lucius L. and characterized by a high water temperature at sampling, high annual mean temperature, large catchment area, and low altitude (Figure 2, Table 3). Cluster 0 at the bottom left of the SOM was occupied by the two stickleback species, and characterized by a low altitude, high annual mean temperature, low water temperature at sampling, and high percentage of urban areas in the catchment. Brook trout was present in sites clustered at the bottom right of the SOM, indicating preference for cold high-altitude tributaries. Brown trout and stone loach, Barbatula barbatula (L.), seemed to occupy two clusters simultaneously, whereas the occurrence of brook lamprey could not be linked with any of the studied environmental variables (Table 3, Figure 2).

The ranking of species in the mean air temperature gradient revealed the two stickleback species favored a warm environment, whereas minnow appeared to be the ultimate cold-water species (Figure 3).

\section{4 | DISCUSSION}

Modeling fish species occurrence in small boreal streams with a logistic regression and self-organizing map indicated clear speciesenvironment relationships. The obtained species clusters and their associations with mainly map-based variables appeared ecologically reasonable and largely concordant with species groupings in the current bioassessment developed for larger boreal streams (Vehanen et al., 2010). The results support the development of fish-based bioassessment for small streams and help in predicting fish assemblage changes in a warming climate.

The effect of small-scale local factors on controlling the occurrence of lotic fish species has been found in numerous studies (Lamouroux et al., 1999; Wang et al., 2003; Watson \& Hillman, 1997). However, the dominance of large-scale regional factors affecting riverine fish assemblages has also been documented (DeRolph et al., 2015; Koel \& Peterka, 2003; Mitsuo, 2017). A wide variety of hypotheses or theories has been put forward concerning the balance of local and regional factors affecting riverine fish assemblages. It has been hypothesized that large-scale processes determine the pool of the fish species available to occur, whereas small-scale processes eventually define the subset of fish species inhabiting a given site (Pont et al., 2005). Although local habitat conditions may be important determinants of fish abundance, they may be of limited importance in determining presence and absence (Porter et al., 2000). Sensitivity to local- and regional-scale processes has been found species-specific (Pont et al., 2005). It was suggested that local factors were most important to fish in minimally impaired watersheds, but the effects of landscape-scale factors become increasingly important as watersheds are increasingly modified by human activities (Wang et al., 2003). However, a combination of local and regional variables has often managed to explain a great deal of the variance in riverine fish occurrence or density (Park et al., 2006; 
FIGURE 1 Occurrence of three fish species as a function of catchment area and altitude

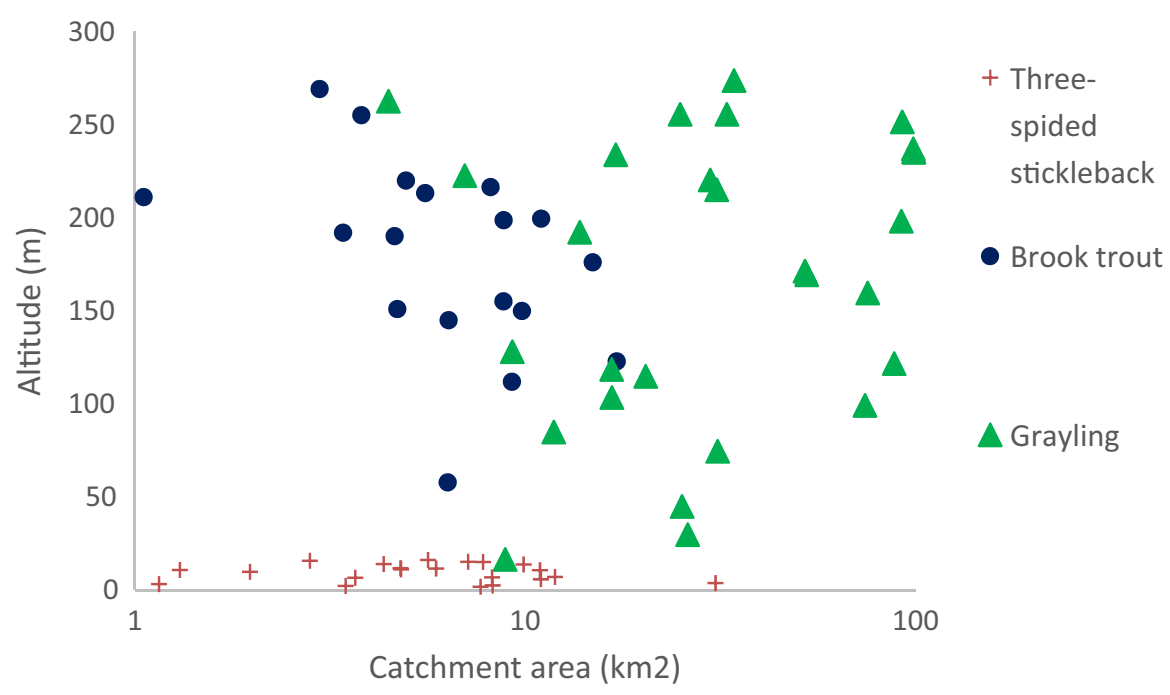

Pont et al., 2005; Ripley et al., 2005). Obviously, both local and regional variables have an effect, and the inclusion of local variables in our models would probably have enhanced the predictive power. However, our results encourage the use of map-based (regional) variables in modeling the species-environment relationships in small streams, especially when confronting limited resources to control site-specific local variables.

The sensitivity of the BLR model was rather poor, at least compared to specificity (Table 2 ). The relatively small size of the electrofishing area and the use of a single-run electrofishing sampling in this study may have decreased the probability of getting all the fish species in the catch. The information generated by single-visit surveys of fish occurrence cannot account for intra-annual or interannual variation in the upstream extent of fish distribution (Fransen et al., 2006). Small streams are vulnerable to drought events inducing temporal variation in fish assemblages (Grossman et al., 1998; Keaton et al., 2005). Our model's prediction of species occurrence and absence may be of use in extending the current fish-based bioassessment (Vehanen et al., 2010) to small brooks. For management and inventory purposes, we recommend the application of larger data and cross-validation in BLR.

The SOM clusters of fish species and environmental variables appeared plausible. Cluster 0 was occupied by two stickleback species that seemed to favor warm regions, low altitude, and the high share of urban areas in the upper catchment. Sticklebacks have been considered to indicate degradation in lowland brooks (Fieseler \& Wolter, 2006). Freshwater fish communities have been found sensitive to watershed urbanization (Chen \& Olden, 2020).

The occurrence of perch, roach, and northern pike (Cluster 1 in SOM) was associated with a high annual mean temperature, a relatively large catchment area, low altitude, and lakes in the upper catchment. These three fish species are common lake species (Maitland \& Campbell, 1992) possibly spreading to small streams at warm-water periods (Degerman \& Sers, 1994; Sutela et al., 2017). This trait was supported by the frequent occurrence of these species with high temperature at sampling (Table 3). The occurrence of bullhead, burbot, grayling, and minnow was associated with a relatively large catchment area, a high altitude, a low mean temperature, and open mires in the catchment (Cluster 2). The fish species in this cluster can be characterized as cold-water species (Logez et al., 2012) living in forested peatland regions. The only fish species centering cluster 3 , brook trout, favored cold, and small high-altitude streams. Brook trout is an alien invader species in Europe, having been stocked in many Finnish tributary streams. Brook trout also prefers small tributary streams in its home district in North America (Kanno et al., 2015). Alien brook trout has been found to exclude brown trout in small Finnish brooks (Korsu et al., 2007).

The appearance of the most frequently encountered fish species, brown trout, was centered in clusters 0 and 3 with avoidance of ditched peatland in the upper catchment. The drainage ditching of peatland for forestry causes the erosion and deposition of fine sediments in headwater streams, accompanied by nutrient loading (Marttila \& Kløve, 2010; Nieminen et al., 2018). Deposited sediment can diminish salmonid embryo survival by decreasing redd gravel permeability, interstitial water exchange, and therefore oxygen supply (Greig et al., 2007; Louhi et al., 2011; Michel et al., 2014). These impacts may have suppressed the occurrence of brown trout in catchments with a high coverage of ditched peatland in this study.

Climate change scenarios forecast a high increase in the mean air temperature for the European boreal ecoregion (Schneider et al., 2013). Fish species have evolved to fit distinct thermal niches where they can optimize physiological, reproductive, and ecological performance (Coutant, 1987; Graham \& Harrod, 2009). Temperature is one of the key abiotic factors affecting fish species distribution (Matthews, 1998). Globally, fish species living in small headwater streams are especially vulnerable to climate change (Buisson \& Grenouillet, 2009; Buisson et al., 2008). The presented ranking of the fish species along the mean air temperature gradient can help in predicting the effects of a warming climate on fish assemblages in the studied region. The breadth of the thermal range largely delineates the ability of fish species to adapt to climate change (Buisson \& Grenouillet, 2009; Logez et al., 2012). In this study, minnow expressed a relatively narrow thermal range at the cold end of the gradient (Figure 3), suggesting high vulnerability to the warming 


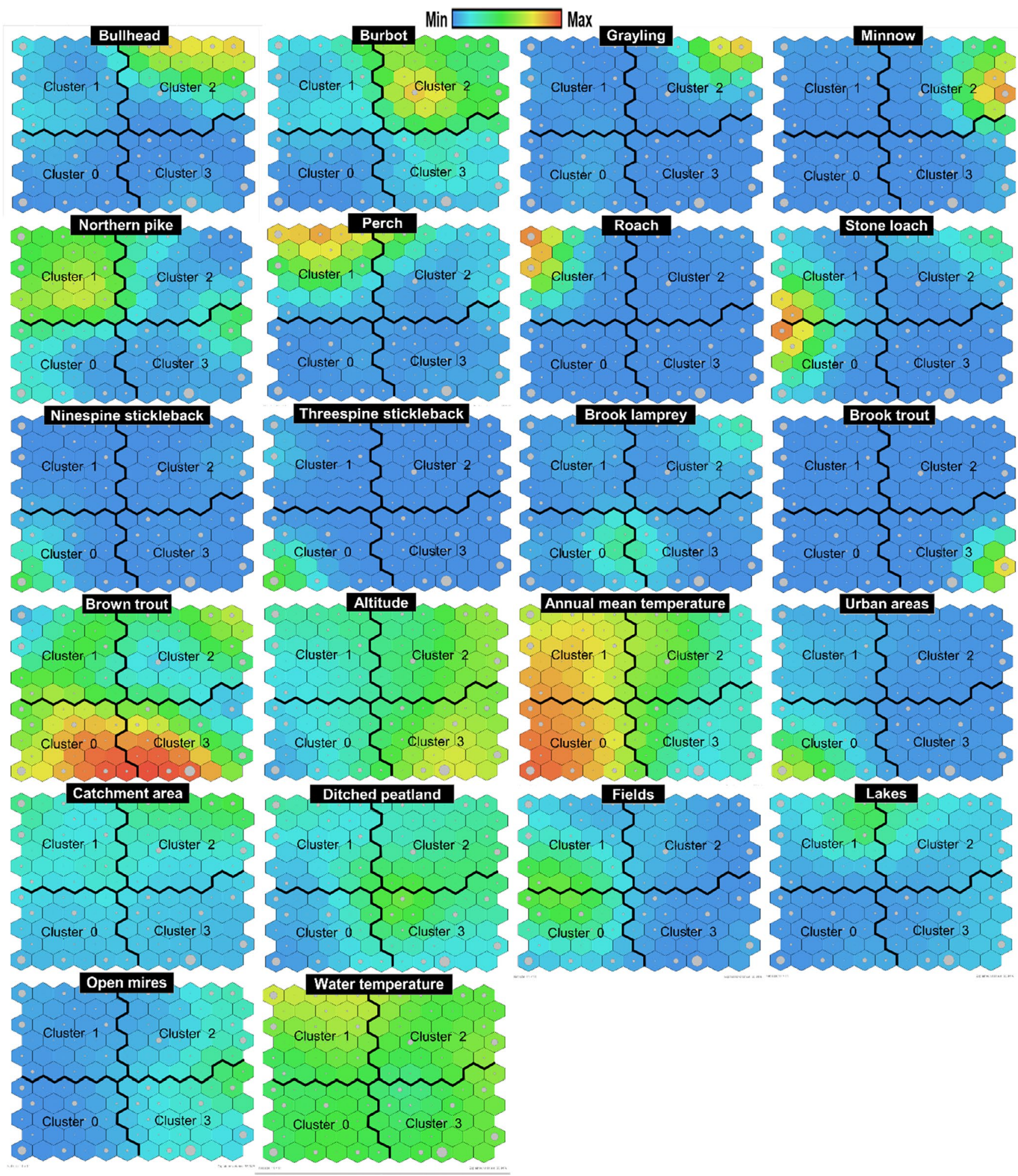

FIGURE 2 Self-organizing maps of 22 predictors with four clusters separated by thick black lines in each figure. For example, in brook trout occurrence is highest in cluster 3, with high-altitude sampling sites and low annual mean temperatures (see cluster 3 in the figure). Each sample (id, row) remains in the same SOM node (cell) in each figure. The sample size of brown trout (255, Table 2) was higher than that of grayling (28, Table 2), and hence, the general coloring of grayling figure in the topmost row is bluer. The size of gray circles represents the number of samples in a cell

climate in this region. The thermal ranges of some fish species (e.g., brown trout, perch, and northern pike) may vary, depending on the size of the catchment area and stream power (Logez et al., 2012).
Accordingly, the inclusion of large rivers in the analyses could result in a different outcome for fish species ordination along the mean temperature gradient. These findings suggest that local stream 
characteristics should be taken into account when predicting the effects of climate change. Besides the increase in the mean air and river water temperature in the European boreal ecoregion, future winter discharges are likely to increase from the natural flow regime, while summer flows will be less impacted (Schneider et al., 2013). The discharge aspect, although probably of minor importance in the boreal region, should also be taken into account when predicting the effects of a warming climate on boreal riverine fish assemblages.

The assessment of the ecological status or integrity of surface waters has been widely established around the world (Karr \& Chu, 2000; Poikane et al., 2020; Xu et al., 2014). In Europe, the legislation to achieve a good ecological status in surface waters is guided by the WFD (European Commission, 2000). Bioassessment methods in rivers have been developed using three biological groups: periphytic diatoms, benthic invertebrates, and fish fauna. Stream biota is often impaired by multiple pressures interacting in additive, synergistic, or antagonistic ways (Schinegger et al., 2012). Diagnostic tools for distinguishing the impacts of different pressures have been called for to target the diminishing measures in water pollution control (Lemm et al., 2019; Poikane et al., 2020). In this study, mapderived pressures of agriculture (fields), urban land cover, and drainage ditching for forestry seemed to affect the occurrence of certain fish species. These results encourage the development of diagnostic fish-based pressure-specific metrics for small boreal streams.

A simple diagnostic tool (index) for evaluating direct effects of climate change could be calculated as an average of two metrics,

TABLE 3 Significance $(p)$ values from the logistic regression analysis run separately for each fish species-predictor pair

\begin{tabular}{|llcccccccc} 
& $\begin{array}{l}\text { Catchment } \\
\text { area }\end{array}$ & Altitude & $\begin{array}{l}\text { Water } \\
\text { temperature }\end{array}$ & $\begin{array}{l}\text { Annual mean } \\
\text { temperature }\end{array}$ & Fields & $\begin{array}{l}\text { Ditched } \\
\text { peatland }\end{array}$ & $\begin{array}{l}\text { Urban } \\
\text { areas }\end{array}$ & $\begin{array}{l}\text { Open } \\
\text { mires }\end{array}$ & \multicolumn{1}{c}{ Lakes } \\
Cluster
\end{tabular}

Notes: Values in bold indicate positive effect $(p<0.05)$, values in italics negative effect $(p<0.05)$, in missing values $p>0.05$. Clusters $0-3$ refer to the SOM analysis results presented in Figure 3.

FIGURE 3 Annual average air temperature at the sites where each of the species occurred ( $N$ in parenthesis)

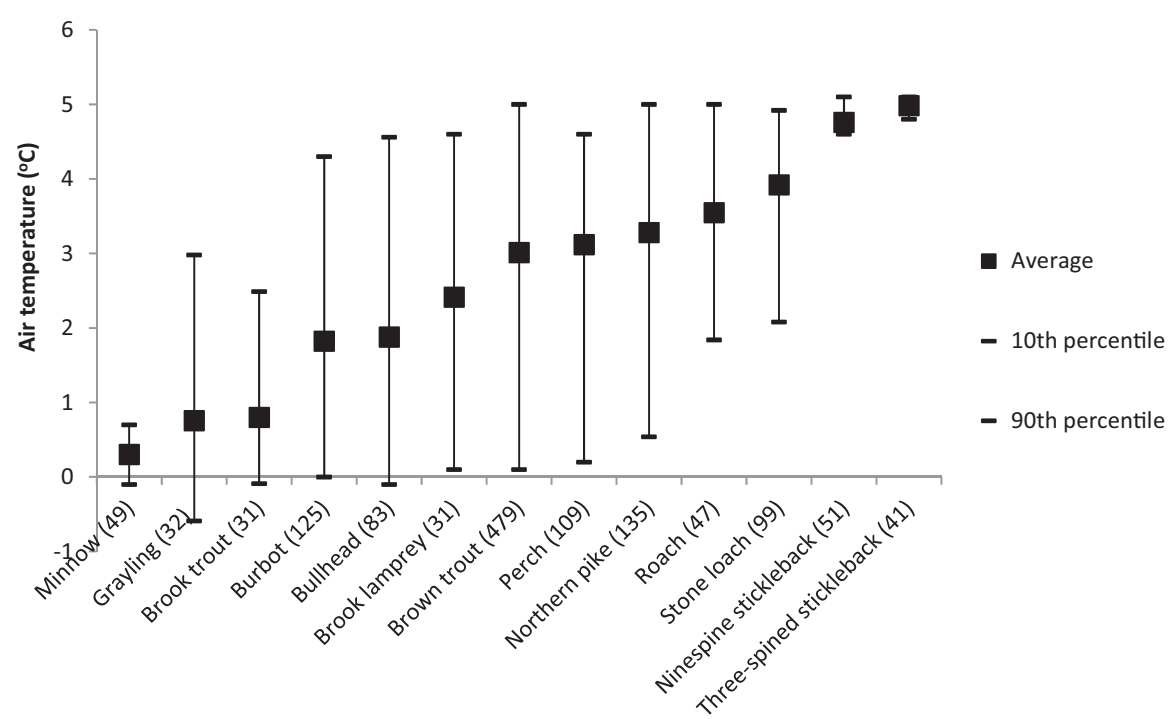


the proportion of cold-water species (climate change intolerants, scaled to $0-1$ ), and the proportion of warm-water species (climate change tolerants, scaled to $0-1$, inverse values) of an electrofishing sample. Referring to Figure 3, in our case the cold-water species could be minnow, grayling and brook trout, and the warm-water species three-spined stickleback, ninespine stickleback, and stone loach. For a wider use of this index, temperature preferences could be achieved like in this study or by using existing knowledge and references about temperature preferences of fish species, such as Logez et al. (2012). Possible indirect effects of climate change stemming from flushing of nutrients (Wilby et al., 2006), for instance, could be integrated to the index following the basics presented in Hering et al. (2006).

In the fish-based integrity indices developed in bioassessment for boreal and northern temperate zone, cool- or cold-water fish species are often classified as intolerant species (Kanno et al., 2010; Vehanen et al., 2010). This feature is also seen in the Figure 3, where seven species from the left indicating favor of cold water can be classified as intolerant (grayling, brook trout, bullhead, brook lamprey, and brown trout) or intermediately tolerant (minnow and burbot) referring to Holzer (2008). Respectively, the six species on the right-hand side indicating favor of warm water can be classified as tolerant (perch, roach, ninespine stickleback, and three-spined stickleback) or intermediately tolerant (northern pike and stone loach). The classification of tolerant and intolerant species by Holzer is highly compatible with those used in fish integrity indices, such as Pont et al. (2006), Hughes et al. (2004), Vile and Henning (2018), and Vehanen et al. (2010). Observed pattern in the sequence of species in the temperature gradient in relation to tolerant-intolerant division of species suggests that the integrity indices developed for regions inhabited by these species should respond to the water temperature rise in streams on itself, without the possible influence via indirect effects such as altered discharge regime and flushing of extra nutrients (Wilby et al., 2006). In other words, the effect of climate change strictly as warming of the streams should be (by chance) at least to some extent inborn in many of the present fish indices. As an example, cool-water versus warm-water species balance obviously affects the FiFI index values, which can be easily approximated or calculated based on the metrics by Vehanen et al. (2010). At any rate, when aiming to integrate the effect of global warming to fish indices, the effect of warming on the reference sites should be controlled by referring to the earliest reliable electrofishing data or other historical fish data. This somewhat different approach from the more adaptable attitude to the direct effects of climate change in WFD (Kristensen et al., 2018; Nõges et al., 2007) could be considered also with other biological quality elements.

\section{ACKNOWLEDGMENTS}

We utilized data collected in the Life IP project FRESHABIT (LIFE Programme of the European Union) in this study. The study reflects the views of the authors, and neither the European Commission nor the EASME is responsible for any use that may be made of the information it contains. We thank Hanna Hentilä, Minna Kuoppala, and
Kati Martinmäki-Aulaskari from SYKE and Auli Immonen from Luke for catchment delineation and other GIS work.

\section{CONFLICT OF INTEREST}

The authors declare no conflict of interest.

\section{AUTHOR CONTRIBUTION}

Tapio Sutela: Writing-original draft (lead). Teppo Vehanen: Methodology (supporting); Writing-original draft (supporting). Pekka Jounela: Methodology (lead); Writing-original draft (supporting). Jukka Aroviita: Methodology (supporting); Writing-original draft (supporting).

\section{DATA AVAILABILITY STATEMENT}

Data are available from the Dryad Digital Repository (https://doi. org/10.5061/dryad.6t1g1jwzp).

\section{ORCID}

Tapio Sutela (iD https://orcid.org/0000-0003-4227-9399

Teppo Vehanen (iD https://orcid.org/0000-0003-3441-6787

\section{REFERENCES}

Allan, D., Erickson, D. L., \& Fay, J. (1997). The influence of catchment land use on stream integrity across multiple spatial scales. Freshwater Biology, 37, 149-161. https://doi.org/10.1046/j.1365-2427.1997.d01-546.x

Baattrup-Pedersen, A., Larsen, S. E., Andersen, D. K., Jepsen, N., Nielsen, J., \& Rasmussen, J. (2018). Headwater streams in the EU Water Framework Directive: Evidence-based decision support to select streams for river basin management plans. Science of the Total Environment, 613-614, 1048-1054. https://doi.org/10.1016/j.scito tenv.2017.09.199

Brosse, S., Lek, S., \& Townsend, C. R. (2001). Abundance, diversity, and structure of freshwater invertebrates and fish communities: An artificial neural network approach. New Zealand Journal of Marine and Freshwater Research, 35, 135-145. https://doi.org/10.1080/00288 330.2001 .9516983

Buisson, L., \& Grenouillet, G. (2009). Contrasted impacts of climate change on stream fish assemblages along an environmental gradient. Diversity and Distributions, 15, 613-626. https://doi. org/10.1111/j.1472-4642.2009.00565.x

Buisson, L., Thuillier, W., Lek, S., Lim, P., \& Grenouillet, G. (2008). Climate change hastens the turnover of stream fish assemblages. Global Change Biology, 14, 2232-2248. https://doi. org/10.1111/j.1365-2486.2008.01657.x

Burdon, F. J., Reyes, M., Alder, A. C., Joss, A., Ort, C., Räsänen, K., Jokela, J., Eggen, R. I. L., \& Stamm, C. (2016). Environmental context and magnitude of disturbance influence trait-mediated community responses to wastewater in streams. Ecology and Evolution, 6, 39233939. https://doi.org/10.1002/ece3.2165

Bussi, G., Whitehead, P. G., Gutiérrez-Cánovas, C., Cayetano, P. G., Ledesma, J. L. J., Ormerod, S. J., \& Couture, R.-M. (2018). Modelling the effects of climate and land-use change on the hydrochemistry and ecology of the River Wye (Wales). Science of the Total Environment, 627, 733-743. https://doi.org/10.1016/j.scitotenv.2018.01.295

Chen, K., \& Olden, J. D. (2020). Threshold responses of riverine fish communities to land use conversion across regions of the world. Global Change Biology, 26, 4952-4965. https://doi.org/10.1111/gcb.15251

Chon, T. S. (2011). Self-organizing maps applied to ecological sciences. Ecological Informatics, 6(2011), 50-61. https://doi.org/10.1016/j. ecoinf.2010.11.002 
Coutant, C. C. (1987). Thermal preference: When does an asset become a liability. Environmental Biology of Fishes, 18, 161-172. https://doi. org/10.1007/BF00000356

Davies, D. L., \& Bouldin, D. W. (1979). A cluster SEPARATION MEASURE. IEEE Transactions on Pattern Analysis and Machine Intelligence, PAMI-1, 224-227. https://doi.org/10.1109/TPAMI.1979.4766909

Degerman, E., \& Sers, B. (1994). The effect of lakes on the stream fish fauna. Ecology of Freshwater Fish, 3, 116-122. https://doi. org/10.1111/j.1600-0633.1994.tb00113.x

DeRolph, C. R., Nelson, S. A., Kwak, T. J., \& Hain, E. F. (2015). Predicting fine-scale distributions of peripheral aquatic species in headwater streams. Ecology and Evolution, 5, 152-163. https://doi.org/10.1002/ ece3.1331

Domisch, S., Jähnig, S. C., Simaika, J. P., Kuemmerlen, M., \& Stoll, S. (2015). Application of species distribution models in stream ecosystems: The challenges of spatial and temporal scale, environmental predictors and species occurrence data. Fundamental and Applied Limnology, 186, 45-61. https://doi.org/10.1127/fal/2015/0627

European Commission. (2000). Directive 2000/60/EC of the European Parliament and of the council of 23rd October 2000 establishing a framework for community action in the field of water policy. Official Journal of the European Communities, L327/1.

Fieseler, C., \& Wolter, C. (2006). A fish-based typology of small temperate rivers in the northeastern lowlands of Germany. Limnologica, 36, 2-16. https://doi.org/10.1016/j.limno.2005.10.001

Franklin, J. (1995). Predictive vegetation mapping: Geographic modeling of biospatial patterns in relation to environmental gradients. Progress in Physical Geography, 19, 474-499. https://doi.org/10.1177/03091 3339501900403

Fransen, B. R., Duke, S. D., McWethy, L. G., Walter, J. K., \& Bibly, R. E. (2006). A logistic regression model for predicting the upstream extent of fish occurrence based on geographical information systems data. North American Journal of Fisheries Management, 26, 960-975. https://doi.org/10.1577/M04-187.1

Giraudel, J. J., \& Lek, S. (2001). A comparison of self-organizing map algorithm and some conventional statistical methods for ecological community ordination. Ecological Modelling, 146(1-3), 329-339. https:// doi.org/10.1016/S0304-3800(01)00324-6

Gorman, O. T., \& Karr, J. R. (1978). Habitat structure and stream fish communities. Ecology, 59, 507-515. https://doi.org/10.2307/1936581

Graham, C. T., \& Harrod, C. (2009). Implications of climate change for the fishes of the British Isles. Journal of Fish Biology, 74, 1143-1205. https://doi.org/10.1111/j.1095-8649.2009.02180.x

Greig, S. M., Sear, D. A., \& Carling, P. A. (2007). A review of factors influencing the availability of dissolved oxygen to incubating salmonid embryos. Hydrological Processes, 21, 323-334. https://doi. org/10.1002/hyp.6188

Grossman, G. D., Ratajczak, R. E., Crawford, M., \& Freeman, M. C. (1998). Assemblage organization in stream fishes: Effects of environmental variation and interspecific interactions. Ecological Monographs, 68, 395-420. 10.1890/0012-9615(1998)068[0395:AOISFE]2.0.CO;2

Guisan, A., \& Zimmermann, N. E. (2000). Predictive habitat distribution models in ecology. Ecological Modelling, 135(2-3), 147-186. https:// doi.org/10.1016/S0304-3800(00)00354-9

Hering, D., Feld, C. K., Moog, O., \& Ofenböck, T. (2006). Cook book for the development of a multimetric index for biological condition of aquatic ecosystems: Experiences from the European $\mathrm{AQEM}$ and STAR projects and related initiatives. Hydrobiologia, 566, 311-324. https://doi.org/10.1007/978-1-4020-5493-8_22

Hijmans, J., Cameron, S. E., Parra, J. L., Jones, P. G., \& Jarvis, A. (2005). Very high resolution interpolated climate surfaces for global land areas. International Journal of Climatology, 25, 1965-1978. https:// doi.org/10.1002/joc.1276

Holzer, S. (2008). European Fish Species: Taxa and guilds classification regarding fish-based assessment methods. Diplomarbeit. Universität Wien., 196, https://doi.org/10.25365/thesis.2400
Hosmer, D. W. Jr, \& Lemeshow, S. (1989). Applied logistic regression. Wiley. Hughes, R. M., Howlin, S., \& Kaufmann, P. R. (2004). A biointegrity index (IBI) for coldwater streams of Western Oregon and Washington. Transactions of the American Fisheries Society, 133, 1497-1515. https://doi.org/10.1577/T03-146.1

Huston, M. A. (2005). The three phases of land-use change, Implications for biodiversity. Ecological Applications, 15, 1864-1878. https://doi. org/10.1890/03-5281

Kanno, Y., Letcher, B. H., Rosner, A. L., O'Neil, K. P., \& Nislow, K. H. (2015). Environmental factors affecting brook trout occurrence in headwater stream segments. Transactions of the American Fisheries Society, 144, 373-382. https://doi.org/10.1080/00028487.2014.991446

Kanno, Y., Vokoun, J. C., \& Beauchene, M. (2010). Development of dual fish multi-metric indices of biological condition for streams with characteristic thermal gradients and low species richness. Ecological Indicators, 10, 565-571. https://doi.org/10.1016/j.ecoli nd.2009.09.004

Karr, J. R., \& Chu, E. W. (2000). Sustaining living rivers. Hydrobiologia, 422-423, 1-14.

Kaski, S. (1997). Data exploration using self-organizing maps. Acta Polytechnica Scandinavica, Mathematics, Computing and Management in Engineering Series, 82.

Keaton, M., Haney, D., \& Andersen, C. B. (2005). Impact of drought upon fish assemblage structure in two South Carolina Piedmont streams. Hydrobiologia, 545, 209-223. https://doi.org/10.1007/ s10750-005-2674-z

Koel, T. M., \& Peterka, J. J. (2003). Stream fish communities and environmental correlates in the Red River of the North, Minnesota and North Dakota. Environmental Biology of Fishes, 67, 137-155. https:// doi.org/10.1023/A:1025699512619

Kohonen, T. (1982). Self-organized formation of topologically correct feature maps. Biological Cybernetics, 43, 59-69. https://doi.org/10.1007/ bf00337288

Kohonen, T. (2001). Self-Organizing Maps. Springer Verlag.

Kohonen, T. (2014). MATLAB Implementations and Applications of the Self-Organizing Map. Helsinki, Unigrafia Oy. Retrieved from http:// docs.unigrafia.fi/publications/kohonen_teuvo/index.html

Korsu, K., Huusko, A., \& Muotka, T. (2007). Niche characteristics explain the reciprocal invasion success of stream salmonids in different continents. Proceedings of the National Academy of Sciences of the United States of America, 104, 9725-9729. https://doi.org/10.1073/ pnas.0610719104

Kristensen, P., \& Globevnik, L. (2014). European small water bodies. Biology and Environment: Proceedings of the Royal Irish Academy, 114B(3), 281-287. https://doi.org/10.3318/bioe.2014.13

Kristensen, P., Whalley, C., Néry, F., Zal, N., \& Christiansen, T. (2018) European waters. Assessment of status and pressures 2018. EEA Report, 7/2018. https://doi.org/10.2800/303664

Lamouroux, N., Capra, H., Pouilly, M., \& Souchon, Y. (1999). Fish habitat preferences in large streams of southern France. Freshwater Biology, 42, 673-687. https://doi.org/10.1046/j.1365-2427.1999.00521.x

Lange, K., Townsend, C. R., Gabrielsson, R., Chanut, P. C. M., \& Matthaei, C. D. (2014). Responses of stream fish populations to farming intensity and water abstraction in an agricultural catchment. Freshwater Biology, 59, 286-299. https://doi.org/10.1111/fwb.12264

Lemm, J. U., Feld, C. K., \& Birk, S. (2019). Diagnosing the causes of river deterioration using stressor-specific metrics. Science of the Total Environment, 651, 1105-1113. https://doi.org/10.1016/j.scito tenv.2018.09.1570048-9697

Logez, M., Bady, P., \& Pont, D. (2012). Modelling the habitat requirement of riverine fish species at the European scale: Sensitivity to temperature and precipitation and associated uncertainty. Ecology of Freshwater Fish, 21, 266-282. https://doi. org/10.1111/j.1600-0633.2011.00545.x

Louhi, P., Ovaska, M., Mäki-Petäys, A., Erkinaro, J., \& Muotka, T. (2011). Does fine sediment constrain salmonid alevin development and 
survival? Canadian Journal of Fisheries and Aquatic Sciences, 68, 18191826. https://doi.org/10.1139/F2011-106

Lü, G., Batty, M., Strobl, J., Lin, H., Zhu, A.-X., \& Chen, M. (2019). Reflections and speculations on the progress in Geographic Information Systems (GIS): A geographic perspective. International Journal of Geographical Information Science, 33(2), 346-367. https:// doi.org/10.1080/13658816.2018.1533136

Maitland, P. S., \& Campbell, R. N. (1992). Freshwater Fishes (pp. 368). Harper Collins.

Marttila, H., \& Kløve, B. (2010). Dynamics of erosion and suspended sediment transport from drained peatland forestry. Journal of Hydrology, 388, 414-425. https://doi.org/10.1016/j.jhydrol.2010.05.026

Matthews, W. J. (1998). Patterns in Freshwater Fish Ecology. Chapman \& Hall.

Michel, C., Schindler-Wildhaber, Y., Epting, J., Thorpe, K. L., Huggenberger, P., Alewell, C., \& Burkhardt-Holm, P. (2014). Artificial steps mitigate the effect of fine sediment on the survival of brown trout embryos in a heavily modified river. Freshwater Biology, 59, 544-556. https://doi. org/10.1111/fwb.12284

Mierswa, I., Wurst, M., Klinkenberg, R., Scholz, M., \& Euler, T. (2006). Yale, Rapid prototyping for complex data mining tasks. Proceedings of the 12th ACM SIGKDD international conference on knowledge discovery and data mining (KDD-06). https://doi.org/10.1145/1150402.1150531

Mitsuo, Y. (2017). Determining the relative importance of catchment and site-scale factors in structuring fish assemblages in small coastal streams. Knowledge \& Management of Aquatic Ecosystems, 418, 1-6. https://doi.org/10.1051/kmae/2017046

Nelson, R. L., Plaits, W. S., Larsen, D. P., \& Jensen, S. E. (1992). Trout distribution and habitat in relation to geology and geomorphology in the North Fork Humboldt River drainage, northeastern Nevada. Transactions of the American Fisheries Society, 121, 405-426. https:// doi.org/10.1577/1548-8659(1992)121<0405:TDAHIR>2.3.CO;2

Nieminen, M., Piirainen, S., Sikström, U., Löfgren, S., Marttila, H., Sarkkola, S., Laurén, A., \& Finér, L. (2018). Ditch network maintenance in peat-dominated boreal forests: Review and analysis of water quality management options. Ambio, 47, 535-545. https://doi. org/10.1007/s13280-018-1047-6

Nõges, P., Van de Bund, W., Cardoso, A. C., \& Heiskanen, A.-S. (2007). Impact of climatic variability on parameters used in typology and ecological quality assessment of surface waters-implications on the Water Framework Directive. Hydrobiologia, 584, 373-379. https:// doi.org/10.1007/s10750-007-0604-y

Oberdorff, T., Pont, D., Hugueny, B., \& Chessel, D. (2001). A probabilistic model characterizing fish assemblages of French rivers: A framework for environmental assessment. Freshwater Biology, 46, 399-415. https://doi.org/10.1046/j.1365-2427.2001.00669.x

Oberdorff, T., Pont, D., Hugueny, B., \& Porcher, J. (2002). Development and validation of a fish-based index for the assessment of 'river health' in France. Freshwater Biology, 47, 1720-1734. https://doi. org/10.1046/j.1365-2427.2002.00884.x

Park, Y.-S., Grenouillet, G., Esperance, B., \& Lek, S. (2006). Stream fish assemblages and basin land cover in a river network. Science of the Total Environment, 365, 140-153. https://doi.org/10.1016/j.scito tenv.2006.02.046

Poikane, S., Salas Herrero, F., Kelly, M. G., Borja, A., Birke, S., \& van de Bund, W. (2020). European aquatic ecological assessment methods, A critical review of their sensitivity to key pressures. Science of the Total Environment, 740, 140075. https://doi.org/10.1016/j.scito tenv.2020.140075

Pont, D., Hugueny, B., Beier, U., Goffaux, D., Melcher, A., Noble, R., Rogers, C., Roset, N., \& Schmutz, S. (2006). Assessing river biotic condition at a continental scale: A European approach using functional metrics and fish assemblages. Journal of Applied Ecology, 43 70-80. https://doi.org/10.1111/j.1365-2664.2005.01126.x

Pont, D., Hugueny, B., \& Oberdorff, T. (2005). Modelling habitat requirement of European fishes: Do species have similar responses to local and regional environmental constraints? Canadian Journal of Fisheries and Aquatic Sciences, 62, 163-173. https://doi. org/10.1139/F04-183

Porter, M. S., Rosenfeld, J., \& Parkinson, E. A. (2000). Predictive models of fish species distribution in the Blackwater Drainage, British Columbia. North American Journal of Fisheries Management, 20, 349359. https://doi.org/10.1577/1548-8675(2000)020<0349:PMOFS D>2.3.CO;2

Pugh, M. W., Pandolfi, G., Franklin, T., \& Gangloff, M. M. (2020). Influences of in-stream habitat and upstream land-use on site occupancy of the Kanawha darter (Etheostoma kanawhae), A narrowly distributed species from the New River (Upper Kanawha Basin). Aquatic Conservation: Marine and Freshwater Ecosystems, 2020, 1-10. https:// doi.org/10.1002/aqc.3473

Rieman, B. E., \& Mclntyre, J. D. (1995). Occurrence of bull trout in naturally fragmented habitat patches of varied size. Transactions of the American Fisheries Society, 124, 285-296. https://doi. org/10.1577/1548-8659(1995)124<0285:OOBTIN>2.3.CO;2

Ripley, T., Scrimgeour, G., \& Boyce, M. S. (2005). Bull trout (Salvelinus confluentus) occurrence and abundance influenced by cumulative industrial developments in a Canadian boreal forest watershed. Canadian Journal of Fisheries and Aquatic Sciences, 62, 2431-2442. https://doi. org/10.1139/F05-150

Schinegger, R., Trautwein, C., Melcher, A., \& Schmutz, S. (2012). Multiple human pressures and their spatial patterns in European running waters. Water and Environment Journal, 26, 261-273. https://doi. org/10.1111/j.1747-6593.2011.00285.x

Schneider, C., Laize, C. L. R., Acreman, M. C., \& Flörke, M. (2013). How will climate change modify river flow regimes in Europe? Hydrology and Earth System Sciences, 17, 325-339. https://doi.org/10.5194/ hess-17-325-2013

Sutela, T., Vehanen, T., Huusko, A., \& Mäki-Petäys, A. (2017). Seasonal shift in boreal riverine fish assemblages and associated bias in bioassessment. Hydrobiologia, 787, 193-203. https://doi.org/10.1007/ s10750-016-2959-4

Terra, B. F., Hughes, R. M., \& Araujo, F. G. (2016). Fish assemblages in Atlantic forest streams: The relative influence of local and catchment environments on taxonomic and functional species. Ecology of Freshwater Fish, 25, 527-544. https://doi.org/10.1111/eff.12231

Vehanen, T., Sutela, T., \& Korhonen, H. (2010). Environmental assessment of boreal rivers using fish data - a contribution to the Water Framework Directive. Fisheries Management and Ecology, 17, 165175. https://doi.org/10.1111/j.1365-2400.2009.00716.x

Vesanto, J., \& Alhoniemi, E. (2000). Clustering of the self-organizing map. IEEE Transactions on Neural Networks and Learning Systems, 11, 586600. https://doi.org/10.1109/72.846731

Vesanto, J., Himberg, J., Siponen, M., \& Simula, O. (1998). Enhancing SOM based data visualization. In Proceedings of the International Conference on Soft Computing and Information/Intelligent Systems (IIZUKA'98), lizuka, Japan (pp. 64-67).

Vile, J. S., \& Henning, B. F. (2018). Development of indices of biotic integrity for high-gradient wadeable rivers and headwater streams in New Jersey. Ecological Indicators, 90, 469-484. https://doi.org/10.1016/j. ecolind 2018.03.027

Wang, L., Lyons, J., Kanehl, P., \& Bannerman, R. (2001). Impacts of urbanization on stream habitat and fish across multiple spatial scales. Environmental Management, 28, 255-266. https://doi.org/10.1007/ s0026702409

Wang, L., Lyons, J., Rasmussen, P., Seelbach, P., Simon, T., Wiley, M., Kanehl, P., Baker, E., Niemela, S., \& Stewart, P. M. (2003). Watershed, reach, and riparian influences on stream fish assemblages in the Northern Lakes and Forest Ecoregion, USA. Canadian Journal of Fisheries and Aquatic Sciences, 60, 491-505. https://doi.org/10.1139/ F03-043

Watson, G. W., \& Hillman, T. W. (1997). Factors affecting the distribution and abundance of bull trout, an investigation at hierarchical scales. 
North American Journal of Fisheries Management, 17, 237-252. https:// doi.org/10.1577/1548-8675(1997)017<0237:FATDAA>2.3.CO;2

Wilby, R. L., Orr, H. G., Hedger, M., Forrow, D., \& Blackmore, M. (2006). Risks posed by climate change to the delivery of Water Framework Directive objectives in the UK. Environment International, 32, 10431055. https://doi.org/10.1016/j.envint.2006.06.017

Xu, M., Wang, Z., Duan, X., \& Pan, B. (2014). Effects of pollution on macroinvertebrates and water quality bio-assessment. Hydrobiologia, 729, 247-259. https://doi.org/10.1007/s10750-013-1504-y
How to cite this article: Sutela, T., Vehanen, T., Jounela, P., \& Aroviita, J. (2021). Species-environment relationships of fish and map-based variables in small boreal streams: Linkages with climate change and bioassessment. Ecology and Evolution, 11, 10457-10467. https://doi.org/10.1002/ece3.7848 